\title{
A gyömbér posztoperatív hányinger- és hányáscsillapító hatásának metaanalízise
}

Tóth Barbara $^{1, *}$, Lantos Tamás ${ }^{2}$, Hegyi Péter ${ }^{3}$, Viola Réka ${ }^{4}$, Csupor Dezsö $^{1}$

${ }^{1}$ SZTE Farmakognóziai Intézet, 6720 Szeged, Eötvös utca 6.

${ }^{2}$ SZTE Orvosi Fizikai és Orvosi Informatikai Intézet, 6720 Szeged, Rerrich Béla tér 1.

${ }^{3}$ PTE Transzlációs Medicina Intézet, 7624 Pécs, Szigeti út 12.

${ }^{4}$ SZTE Klinikai Gyógyszerészeti Intézet, 6725 Szeged, Szikra utca 8.

*e-mail: toth.barbara@pharmacognosy.hu

A posztoperatív hányinger és hányás gyakori velejárója az általános anesztéziában végzett mútéteknek, és további, súlyos komplikációkhoz (pl. aspirációs tüdőgyulladás, mútéti seb felszakadása, nyelőcsőrepedés, dehidratáció) vezethet. A gyömbért (Zingiber officinale) az emberiség évezredek óta alkalmazza gyógy- és füszernövényként többek között hányinger- és hányáscsillapítás céljából is. A közelmúltban számos humán vizsgálatot végeztek a gyömbér hányinger- és hányáscsillapító hatásának igazolására.

Munkánk célja a gyömbér posztoperatív hányinger- és hányáscsillapító hatásának értékelése a rendelkezésre álló placebókontrollos, randomizált, kettős vak klinikai vizsgálatok metaanalízisével.

A metaanalízist előzetes PROSPERO regisztrációt követően a PRISMA irányelvek alapján készítettük el. Az irodalomkutatást az Embase, a Web of Science, a PubMed és a Cochrane Central Register of Controlled Trials adatbázisok segítségével végeztük. A kvantitatív analízis során azokat a humán klinikai vizsgálatokat vettük figyelembe, amelyekben terápiás dózisú gyömbért per os alkalmaztak mútött betegeken.

A végső statisztikai analízishez tíz klinikai vizsgálatot választottunk ki. A vizsgálatok metaanalízise alapján a gyömbér csökkenti a posztoperatív hányás incidenciáját. Ezen kívül a vizuális analóg skála eredményei alapján a placebóhoz képest a gyömbér szignifikánsan mérsékeli a posztoperatív hányinger és hányás súlyosságát. A posztoperatív hányinger incidenciájára, valamint a sürgősségi hányáscsillapítók alkalmazásának igényére a gyömbér nem volt statisztikailag szignifikáns hatással.

Az általunk elvégzett metaanalízis alapján a gyömbér biztonságos és jól tolerálható alternatív megoldás lehet a mútétet követő hányás előfordulásának csökkentésére. 